\title{
"Lenguaje de figuras y su entendimiento..."* \\ Preparación de un estudio sobre los grafiitis en los conventos de la época colonial
}

\begin{abstract}
$D^{\prime}$ OBRE LOS MUROS de los conventos del siglo Xvi no se encuentran sólo las famosas pinturas con escenas bíblicas, filósofos de la Antigüedad, grutescos y batallas. En la franja de pared que rige estos espacios coloreados, se esconden en muchos monasterios franciscanos y agustinos las huellas de otra expresión artística igualmente importante por calidad y cantidad. M anos a veces anónimas grabaron con la ayuda de alguna punta metálica (hay también presencia de dibujos con lápiz) una serie de magníficas imágenes de estilo y formas sorprendentemente similares en un espacio geográfico que abarca centenas de kilómetros, de Tepoztlán a Actopan, de M alinalco a Epazoyucan, de San M iguel Tzinacantepec a Tepeji del Río, de Tezontepec a Ixmiquilpan, de Cuauhtinchan a Cempoala: iglesias, hombres a caballo, escenas de pesca y caza, barcos, espectáculos populares como el de los voladores, castillos listos para ser quemados, pero también una vasta gama de animales fantásticos, pájaros, santos, ángeles y diablos, monogramas y más raramente, palabras, fechas, firmas y ensayos de caligrafía. Con cámara, cuadernito y un poco de discreción - al principio los guardianes del convento y los otros visitantes se preguntan qué es lo que miro con tanto

* Libro de Chilam Balam de Chumayel, traducción de Antonio M ediz Bolio, M éxico, Conaculta, 1998, p. 7I.
\end{abstract}




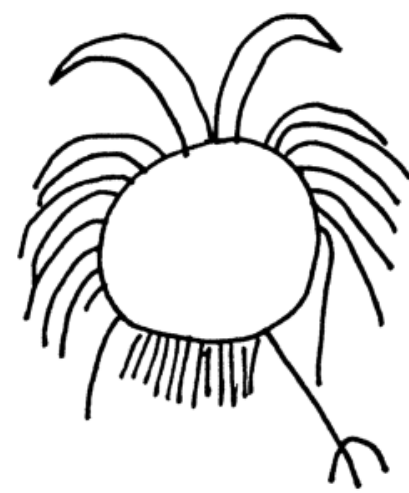

Epazoyucan

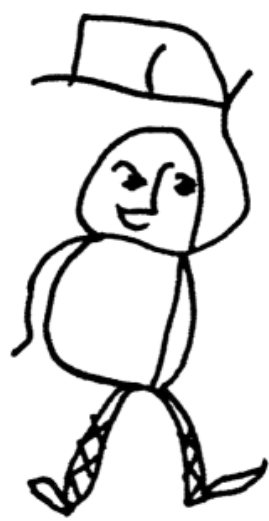

Tezontepec

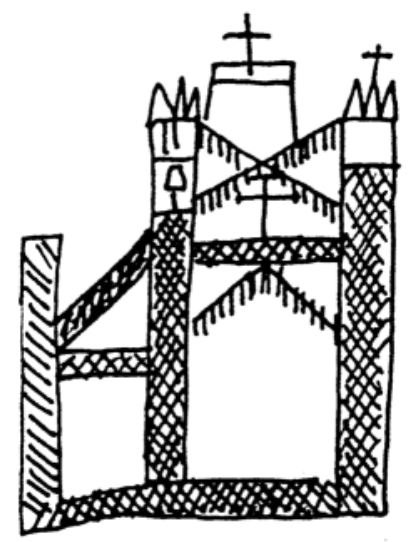

Tepoztlán 


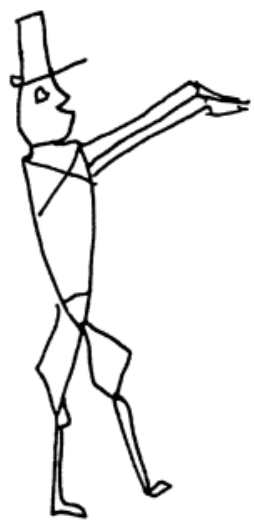

Cempoala

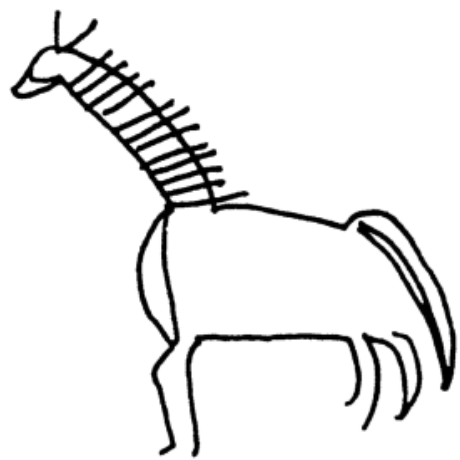

Tepoztlán

afán- estoy buscando y registrando desde hace ya dos años lo que queda de un tipo de creación que tuvo que abarcar un espacio geográfico mucho más amplio de lo que podemos vislumbrar hoy.

Por el momento, es sumamente difícil establecer la datación de los graffitis, expresión artística que pudo alcanzar cierta fama y ser continuada durante varios decenios, o tal vez más de un siglo. Sin embargo, en la comparación con otros tipos de documentos pictográficos como lo son las imágenes de los Títulos primordiales 0 algunas pertenecientes al Ramo Inquisición del Archivo General de la N ación, se puede hipotetizar que hayan sido realizados desde finales del siglo xvi. En Ixmiquilpan se encuentra repetida tres veces una fecha grabada "en I597 años" y en Actopan un graffiti indica "a 7 de agosto el primer dia ı62o en las letrinas de la iglesia aún", fecha que se vuelve efectivamente a encontrar dibujada en las letrinas del convento, junto a otra, i629. Sabemos que estas indicaciones no corresponden necesariamente a la fecha de realización de los graffitis. Sin embargo, la grafía guarda similitudes asombrosas con aquella que podemos encontrar en documentos de la misma época, fijada en tinta a manos de letrados. En Tepeapulco se aprecia fácilmente que la superficie de pintura sobre la cual fueron grabados los graffitis es la misma que la de las pinturas murales. En este caso tampoco estaríamos lejos de los finales del xvi. No hay que descartar la posibilidad de 


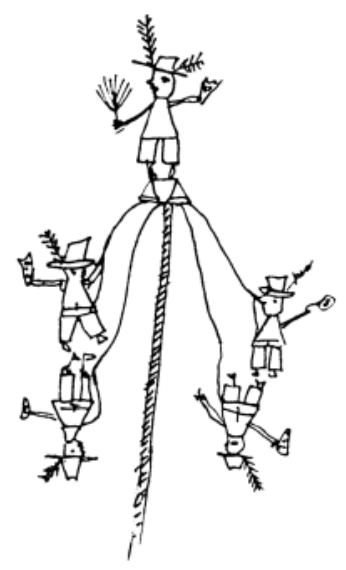

T epeapulco

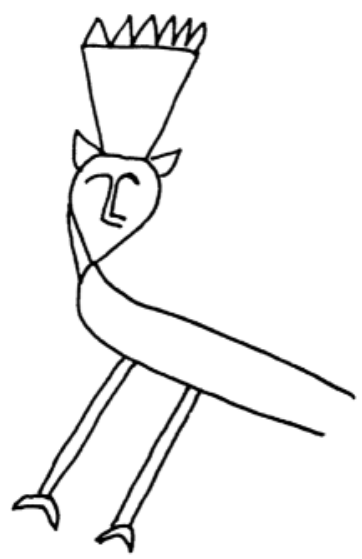

Epazoyucan

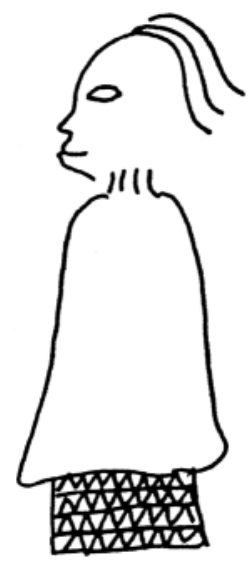

San M iguel Tzinacantepec

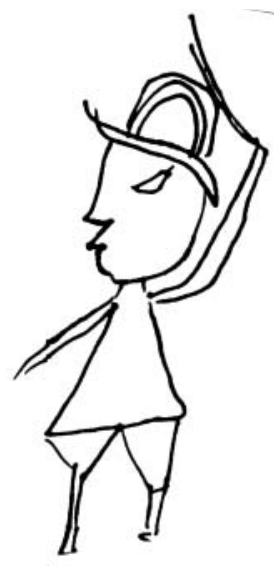

Tepeapulco 

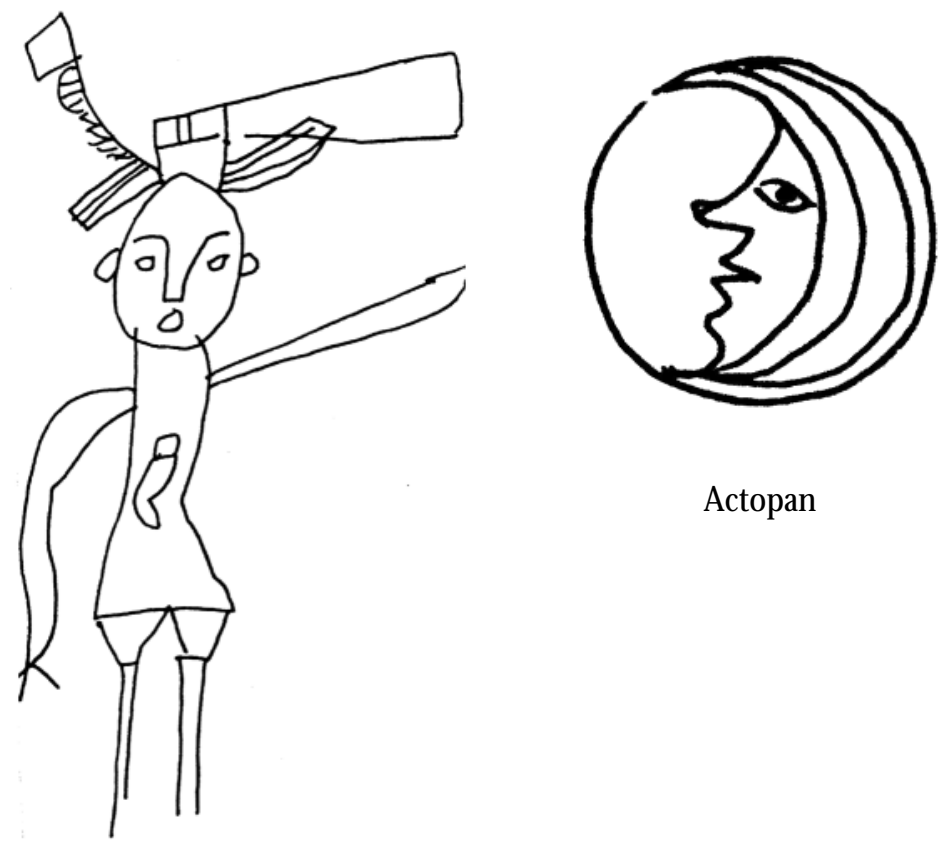

Actopan

Tepoztlán

que se remonten al periodo relativamente largo en que se llevó a cabo la secularización de los conventos, iniciada a principios del siglo xvii y terminada en la segunda mitad del xviii.

En cuanto a la significación de los graffitis coloniales, su homogeneidad y equilibrio estilísticos parecen alejar la hipótesis de que se trate de simple diversión $-y$, aunque así fuera, hay que investigar las categorías plásticas de esta diversión. No creo tampoco que sean síntomas de decadencia de la expresión pictográfica prehispánica. C reo más bien que nos encontramos frente a un tipo de expresión altamente singular que combina una aparente ligereza y fantasía iconográfica con lo que, aparentemente, es una complicadísima estructuración espacial y narrativa.

Antes de que los esbeltos graffitis, invisibles al ojo apresurado, considerados a menudo hechicerías por los sacerdotes, o voluntariamente derrocados y repintados en obras de "resanamiento", se borren o sufran ulterior maltrato, 
192

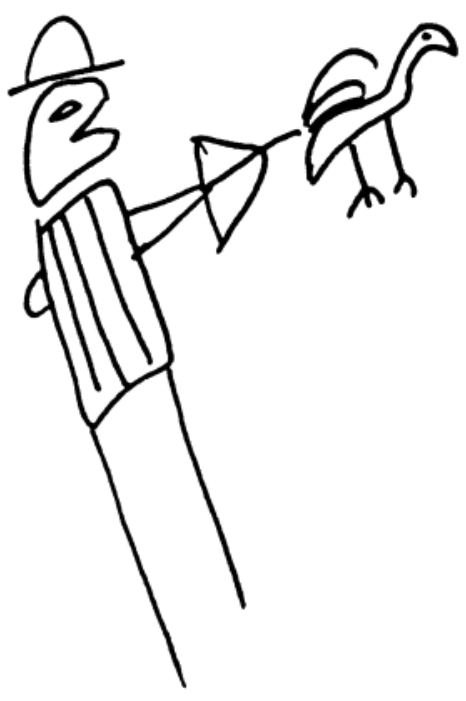

Actopan
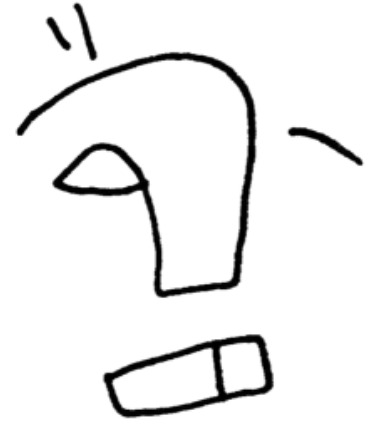

San M iguel Tzinacantepec

la principal intención de esta noticia es subrayar que se trata de un corpus inmenso que antes que todo hay que salvaguardar. Los conjuntos de graffitis que mencioné son de hecho sólo los que encontré entre los conventos recorridos hasta la fecha, aunque mi búsqueda haya abarcado también algunos monasterios de M ichoacán y Yucatán, sin éxito hasta el momento.

Con el deseo de pronto proporcionar en el estudio que preparo una primera lectura más completa de este material excepcional, quiero por el momento invitar a las instituciones que se ocupan de la conservación de los conventos, de guardar con respeto este tesoro: son huellas plásticas, por el momento enigmáticas, que hay que poder seguir mirando con sensibilidad e interpretando con la misma perseverancia y delicadeza con que fueron realizadas. $Y$ quiero sugerir a los visitantes de los conventos del siglo xvi que se mantengan pendientes, dejando bajar los ojos a la altura de la cintura. $Y$, si encuentran algo, si es posible, me avisen... s 